\title{
Development of teaching materials writingdescription using graphic organizer forstudent class $\mathrm{V}$ elementary school
}

\author{
Rahmi Hidayati ${ }^{1}$, Darnis Arief ${ }^{2}$, and Syahniar ${ }^{3}$ \\ ${ }^{123}$ Universitas Negeri Padang, Padang - Indonesia, (rahmih93@gmail.com)
}

\begin{abstract}
This research is based on teaching materials that are less suitable with curriculum demands, less adjusting to writing process (pra writing, when writing, and post writing), and less interest of students to write descriptions. This study aims to determine the validity, practicality and effectiveness of teaching materials write description using Three Word Main Idea Map. The type of research is development research. This research uses 4-D model which consists of 4 stages: define, design, develop, and disseminate. Validity test data obtained through the implementation of RPP sheet, assessment of teacher and student responses. The effectiveness is seen from the activity, the assessment of the process and the result of writing the description. Based on the validity, practicality, and effectiveness test obtained the percentage is very valid, very practical, and very effective for every aspect. Based on the assessment of the results of writing description can be seen the percentage of mastery of writing results increased descriptions. Based on these results, it is concluded that teaching materials to write descriptions using Three Word Main Idea Map developed can improve the skills of writing descriptions.
\end{abstract}

Keywords: Three Word Main Idea, Descriptive

\section{Introducion}

Teaching materials is one means to assist teachers in carrying out teaching and learning activities, especially on learning Indonesian which in the end can improve the quality of learning. Teaching materials are all forms of materials or materials systematically arranged that are used to help teachers or instructors in carrying out teaching and learning activities so as to create an environment or atmosphere that allows students to learn. (Hamdani 2011: 120). The teaching materials that will be discussed this time about teaching materials to help the process of writing in Indonesian language lessons especially for writing skills.

Learning to write in schools tends to teach theories about writing, not how to write the truth, which ultimately leads to the ability of students to put ideas into language low Abidin (2012: 191).The problems in writing descriptive skills are (1) lack of teaching materials as a guide in writing for students, (2) available teaching materials not yet fulfilled in the writing process (prewriting, writing, 
and post-writing) to be achieved from students, (3) ) the existing teaching materials are less interesting for students to write. In addition, (4) the approach to learning writing skills that have not been accurate and (5) the assessment of the skills to write a description that is only assessed in terms of number of paragraphs and other things that are not appropriate ie in terms of neatness writing, and so forth, (6) used less designed by teachers according to the needs and characteristics of students. The teacher uses only a few supporting books. Then, the teaching material only contains the steps to sort the image and then directly ask the students to write the description. (7) The teaching material is also incompatible with KD that is KD 4. "Writing essay based on experience with systematics and proper spelling use". While on the materials, students are asked to write descriptions based on the material that has been determined. This means, less appropriate material with KD to be achieved.

Graphic organizer is one means to assist students in writing descriptions. Graphic organizer are visual displays teachers use to organize information in a manner that makes the information easier to understand and learn. Chien (2012: 50). According to this definition, the Graphic organizer helps the teacher in providing information that is easy to understand and learn.

Graphic Organizer Three Word Main Idea Map is used as a visual medium that shows the relationship between important ideas, ideas and facts that occur. Through the Graphic Organizer of the Three Word Main Idea Map, students study the relationship between the parts or elements of the object observed with the created essay.

Therefore, the Graphic Organizer of Three Word Main Idea Map can be used for writing descriptive skill by developing ideas in the form of skeleton essay based on predetermined theme. Through the Graphic Organizer Three Word Main Idea Map students are led to focus themes and then create a framework and develop ideas in a coherent manner.

So Graphic Organizer displays the elements in creating an essay and loading the writing process. This research can be a consideration of the use of Graphic Organizer in developing teaching materials to improve writing skill, and need to include writing process (prawriting, when writing dam post writing) so that writing skill becomes better. This study is also expected to be used as a variety of learning strategies for teachers to empower students' writing skills in learning.

Based on the background and restrictions of the issues presented above, the following problems can be formulated:

1. How does teaching material write valid descriptions using Graphic Organizer Three Word Main Idea Map for Grade V Elementary Students?

2. How do teaching materials write practical descriptions using Graphic Organizer Three Word Main Idea Map for Grade V Elementary Students?

3. How do teaching materials write effective descriptions using Graphic Organizer Three Word Main Idea Map for Grade V Elementary Students?

The purpose of the study is the first direction to determine the steps in research activities. The purpose of this study is to explain the valid, practical and effective or not: The expected objectives in this research are to:

1. Produce a write description material using Graphic Organizer for valid Grade V SD students.

2. Generate a writing description material using Graphic Organizer for a practical grade V SD student.

3. Produce a writing description material using Graphic Organizer for effective grade V SD students. 


\section{Product Specsifications expected are:}

The resulting product is a writing skills writing skill with Graphic Organizer of Three Word Main Idea Map in class V SD. Development of teaching materials of writing skills description Graphic Organizer in class V SD is a scope of material involving skills in Indonesian language by using step Graphic Organizer in class V SD. Product development is planned to have a match between the learning stages of Indonesian language with Graphic Organizer to be used. Product teaching materials writing skills based description Graphic Organizer in class V SD has the following specifications:

1. Product teaching material to write description with Graphic Organizer Three Word Main Idea Map contains writing process (pre writing, when writing and post writing).

2. The writing process (pre writing, when writing and post writing) is clearly stated in the teaching materials and is accompanied by examples and exercises.

3. Using a language that is easy for students to understand because it is tailored to the level of development of grade V students.

4. Design cover in Graphic Organizer Three Word Main Idea Map using the image of the researchers themselves and combine with various other icons.

5. Having a different icon than others, because it uses cartoon with the researcher's own face.

6. Graphic Organizer Design Three Word Main Idea Map is attractive and with bright colors.

In accordance with PP. 19/2005 article 43 paragraph (5): "The content of the content, language, presentation, and textbook textbook grading is assessed by BSNP and stipulated by Ministerial Regulation." Specifically the planned materials can be described as follows:

1. Aspect of Content or Content

Good teaching materials should contain material that supports the achievement of the SK (competency standard) and KD (basic competencies) of the subject. Eligibility of instructional material content a) material completeness, b) extent, and c) depth. In addition, the material description in the teaching materials implicitly contains material that supports the achievement of minimum SK-KD.

2. Language Aspects

The language used in creating this instructional material should be tailored to the student's progress and the terms of Indonesian Spelling (EBI). Aspects of language should be adjusted to the level of language that is easily understood by students are as follows: a) Written following the rules of Indonesia and terminology is correct and clear, b) in accordance with Level Development and Level of Education Learners, c) communicative, and d) and has unity of Ideas.

3. Aspects of Art

The design of instructional material to be used also takes into consideration aspects of graphics which include: a) Book size / format, b) skin design, c) Design of contents, d) Quality of paper, e) Quality of print, f) Quality of binding.

\section{Model}

The 4-D development model is a model developed by S. Thiagarajan, Dorothy S. Sammel, and Melvyn I. Sammel. According to Thiagarajan et al (1974: 5) the 4-D development model consists of 4 stages: (1) define, (2) design, (3) develop, and (4) disseminate. The four stages that have been disclosed more clearly can be seen through the translation of each taha as follows:

a) Define, aims to define and define the learning requirements that begin with the analysis of the objectives of the developed material constraints.

b) Design stage. Aims to prepare the teaching materials to be developed.

c) Development stage. Aims to produce a revised teaching material based on input from experts. 
d) Dissemination stage. The purpose of this step is to test the effectiveness of the use of teaching materials developed in the learning process. Therefore, this stage is the stage of the use of devices that have been developed on a wide scale such as other schools.

The type of research used in this study is a development research that aims to determine the validity, practicality, and effectiveness of teaching materials to write descriptions. This research was conducted at SDN 07 Ulak Karang Selatan Kota Padang in the odd semester of academic year 2017/2018 which took place the first week of third of November 2017 for 3 meetings. The product test is done in SDN 07 Ulak Karang Selatan Kota Padang with 22 students. The data in this study consisted of evaluating the validity, effectiveness and practicality of a resource writing description.

\section{Results and Discussion}

Based on the validity test, it is found that the average percentage of RPP is $85.28 \%$ from the validator expert with the category is very valid, the validator of the practitioner is $89.90 \%$ with the category is very valid. The result of the average percentage of teaching material is $89,30 \%$ from expert validator with very valid category, from validator of practitioner is $87,08 \%$ with very valid category. Practical test results from the implementation of RPP with the percentage of $89.40 \%$ with very practical category. Assessment of teacher response obtained $86.25 \%$ and assessment of student response $89.99 \%$. The effectiveness of learning tools seen from the activity obtained $88.66 \%$ with very good category. From the assessment of writing process description obtained $88.4 \%$ with very high category. From the assessment of the results of writing description note that the percentage of completeness writing write descriptions tend to increase. Thus, learning to write a description with

Graphic Organizer helps students understand the stages of the writing process description. Based on these results, it was concluded that the teaching materials writing descriptions using Graphic Organizer for grade V SD students developed can be declared valid, practical, and effective.

The development of writing materials description using Graphic Organizer by adopting the 4-D development model has been successfully implemented. The teaching materials have been tested in class V SDN 07 UKS with 22 students and conducted spreading in another school ie SDN 25 ATS in class $\mathrm{V}$ with the number of students are 15 people. Discussion of the results of the development research that has been done, will be further decomposed primarily relating to the validity, practicality, and effectiveness of developed teaching materials. For more details, can be described as follows.

\section{Validity}

Teaching materials that have been developed are said to be valid if they meet certain criteria. The teaching materials should be based on the material or knowledge (content validity) and all components must be consistently linked to each other (construct validity). If the teaching materials meet all the above statements, then the teaching materials can be said to be valid. In this study, the validator will provide an assessment of the teaching materials to be developed. If it meets all of the above statements then the result of the validator's judgment states that the teaching materials are worthy of use with revision or without revision based on a strong theoretical foundation. (Purboningsih, 2015: 468).

Furthermore, the components of the product must be consistent with each other (construct validity). Therefore, the validation of the material to write a description using the Graphic Organizer emphasizes the content and constructs. In this study validation is detailed again into product validation conducted on content, language, presentation and kegrafikaan. Validation in this study was conducted by three expert validators and three validator practitioners. The validation results from the experts were collected and then analyzed to find the average of each indicator and each aspect. The results of this validation are described as follows: 
a. RPP

The process of RPP validation is done based on several aspects according to RPP components: identity, formulation of indicators, formulation of learning objectives, selection of teaching materials, resource selection and instructional media, preparation of learning activities, and assessment. Based on predefined categories, the developed RPP belongs to a very valid category. The developed RPP describes the suitability of all components and activities and concepts that have been contained in it. Compliance is evident from the indicators and objectives of learning that have been formulated, the selected material, learning steps, media and learning resources, and assessments made. That is, in general has been able to describe the components of RPP in accordance with Permendiknas Number 41 of 2007.

b. Teaching materials

Based on the result of data analysis of validation of teaching materials by expert validators and validator of practitioner obtained percentage $88,32 \%$. When viewed from that category has been established then the teaching materials that have been developed pertained to category is very valid. Therefore, it can be concluded that the teaching materials are developed in accordance with the curriculum demands. The presentation of the material has in accordance with the indicators formulated and in accordance with the developments students. The content of the teaching materials has also been in accordance with the writing material in class V SD. The various concepts and elaborations of the tasks contained in the teaching materials make it easier for students to develop the ideas contained in their thoughts into the description form. The contents of the instructional materials are available achieving the basic competencies that are selected. In addition, the use of inner languageteaching materials using sentences that are simple and easily understood by students. Sentence by sentence using the correct spelling. Then, teaching materials developed in the design with an attractive color that is color dominant blue and green so it can motivate students to follow learning process well. Thus it can be concluded that developed teaching materials have been declared valid and can be used in the learning process.

\section{Practicality of Teaching Material}

Practicality of learning devices is related to convenience use of tools used by teachers and students. Arikunto (2010: 62) explains that "praktikalitas or practicality, which means easy to implement, easy examination, and equipped with clear instructions to facilitate teachers and students in the use of learning devices used. To see if the lesson developed is practical or not, a student test is conducted class V SDN 07 UKS. Looking at the RPP that has been developed before, then the learning process is done once with the allocation of time 3x35 minutes. The observed practice is the level of implementation of RPP, the questionnaire teacher response, questionnaire of student response to learning device practicity. For more details can be seen discussion follows.

\section{Implementation of RPP}

The observation results of the implementation of RPP show the learning is done in accordance with the planning that has been made. This can be seen from the results data observation of the implementation of RPP has been very good. This data shows that RPP developed very practical use in learning writing description by using Graphic Organizer. During the trial, no found significant constraints by teachers in implementing the process learning although a little short of time, but can be overcome with optimal class conditioning.

\section{Results of Teacher Response Data Analysis of Writing Materials \\ Description Using Graphic Organizer}

The results of the analysis on the teacher response questionnaire indicate that the writing material description using Graphic Organizer developed very practical use in the learning process. This can be seen from the distribution answers the teacher asked the answer about the teaching materials used. 
As a result, the teacher stated that the developed teaching materials are different with previous teaching materials and easy to use in the learning process. In addition, the exercises provided on the teaching materials are helpful students in pouring the ideas contained in his mind to in the form of a coherent description. Thus, based on that data obtained, the teaching materials developed very practical use in the process learning to write a description in grade V SD.

\section{Results of Student Response Data Analysis of Teaching Materials}

\section{Write Description Graphic Organizer}

The results of the analysis of the student response questionnaire indicated that the students became easier in writing descriptions and had many ideas for writing. The developed teaching material is also interesting for students because it is designed with a more attractive color that is dominant blue and green and in accordance with the characteristics of student development. This is evident from the results of student responses that the teaching materials used are practically used in the learning process. students argue that the readability of teaching materials is clear and easy to understand. This means that the students are very helpful in understanding the stages of writing a good description.

\section{Observation Results of Use of Teaching Materials.}

The observation result is the level of ease of students in using developed teaching materials. Based on the results of observations in general obtained the description description of the activities that students feel easy to use the developed teaching materials. Students feel easy to understand the various concepts and steps of activities that exist in teaching materials. Then the students look interested and enthusiastic and actively involved doing various tasks on the teaching materials.

\section{The effectiveness of teaching materials}

A teaching material can be said to be effective if it brings a good effect or influence on the achievement of learning objectives. Teaching materials are said to be effective if students are successful in the learning process and there is consistency between the curriculum, the student learning experience, and the learning achievement. In this study, teaching materials are said to be effectively demonstrated by the test of learning outcomes in accordance with the KKM (Purboningsih, 2015: 469). Based on the results of the effectiveness test at the development stage shows the average results of the assessment of writing skills description has shows a high percentage. Based on the results of data analysis of student activity when the learning process at meeting I obtained an average value of $87.5 \%$ with very very high category. Then for the process skill assessment write the description done obtained an average value of $85.4 \%$ with categories very high. In the assessment of student outcomes, students get grades reached KKM with $80.9 \%$ percentage of very high category.

In learning 2, the students' activity average is $88,6 \%$. With very high category. Then for the process skill assessment write a description that is done obtained an average value of $90.1 \%$ with very high category. In the assessment of student outcomes, students get the value of reaching KKM with a very high percentage $95.4 \%$ category. In learning 3 obtained the average student activity $88.6 \%$. With very high category. Then for the assessment of the skill of the process of writing the descriptions done obtained an average value of $88.3 \%$ with very high category. In the assessment of student outcomes, students get the value of reaching KKM with a very high $90.9 \%$ category percentage. The level of effectiveness of teaching materials is also reinforced by data at the deployment stage. The result of data analysis on student activity during follow the learning process from three times meeting got the average value $89,2 \%$ with very good category. Furthermore, the assessment process of writing skill descriptions carried out obtained an average value of $86.9 \%$ with very high category. As for the assessment of the results of writing a description, students who completed the third meeting an average of $90 \%$. 


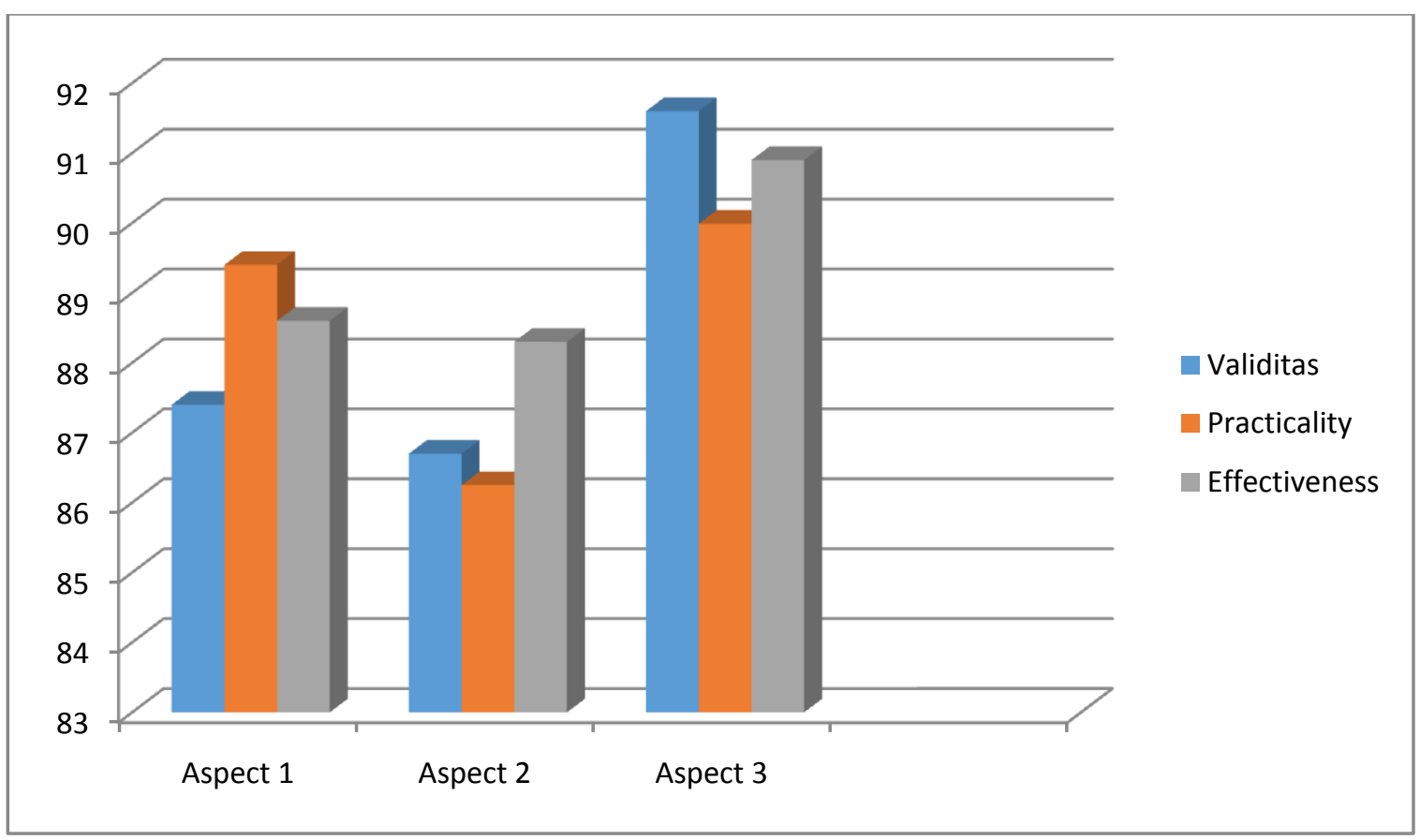

Table 1. Recapitulation of Teaching Materials Assessment

\section{Information of Diagram}

Aspect 1 (Contens). for Validityof Teaching Materials Assessment, the value is $87 \%$ for Practicalityof Teaching Materials Assessment, the value of $89 \%$ for Effectivenessof Teaching Materials Assessment, the value of $88,5 \%$.

Aspect 2 (Language)for Validityof Teaching Materials Assessment, the value is 86,5\%for Practicalityof Teaching Materials Assessment, the value of $86 \%$ for Effectivenessof Teaching Materials Assessment, the value of $88 \%$.

Aspect 3 (Art)for Validityof Teaching Materials Assessment, the value is 91,5\%for Practicalityof Teaching Materials Assessment, the value of 89,5\%for Effectivenessof Teaching Materials Assessment, the value of $90,5 \%$.

\section{Conclusions}

Material Validity Writing Material Description Using Graphic Organizer in Class V Primary School. The validity of teaching materials writing descriptions using Graphic Organizer in Grade V Primary School developed in this study is valid in terms of content and constructs. This corresponds to the validation result of the validator experts and validators of education practitioners

This shows that the fourth aspects of the teaching materials, namely: aspects of content, linguistic aspects, aspects of presentation and aspects of the graft have been prepared in a complete and in accordance with the needs students.

Practicality of Teaching Material Writing Description Using Graphic Organizer in Class V Primary School. Practicality of teaching material writing Description Using Graphic Organizer in Grade V Elementary School as a whole on the category is very practical. This is obtained from the observation of the implementation of RPP on teachers who teach, teacher responses, student responses, and observation sheet of the use of teaching materials. 
This result gives an illustration that the teaching material is very practical and can assist in carrying out the learning process of writing description in class V Elementary School. Effectiveness of Teaching Materials Write Descriptions Using Graphic Organizer in Grade V Elementary School. The effectiveness of teaching material writing Description using Graphic Organizer in class V Primary School can be known through the activities of participants students, process assessments, and assessment of the results of writing student descriptions. Student activity observation, process assessment, and result assessment write student description. The effectiveness of teaching materials as a whole has been done very well.

\section{Suggestions}

1. For teachers, in order to use the teaching materials that have been developed valid in Indonesian language learning especially in learning to write a description.

2. It is expected that teachers can utilize teaching materials that have been developed this is practical in the implementation of the learning process Indonesian, especially in learning to write a description.

3. It is expected that teaching materials that have been developed can be used effectively to improve the writing skills of students, especially on learning to write a description.

4. For researchers, teaching materials that have been developed to be a reference in developing other related primarily related materials with learning Indonesian, in order to obtain effective learning in Primary School.

5. For future researchers, can be used as a reference to conduct research.

\section{References}

Abidin, Y. 2012. Pembelajaran Bahasa Berbasis Pendidikan Karakter. Bandung: Refika Aditama. BSNP. (2006). Panduan Penyusunan Kurikulium Tingkat Satuan Keguruan. Jakarta: Depkiknas.

Depdiknas. 2006. Panduan Penyusunan Kurikulum Tingkat Satuan Pendidikan. Jakarta: Depdiknas.

Hamdani. 2011. Strategi Belajar Mengajar. Bandung: Pustaka Setia.

McKnight, K. S. 2013. The Elementary Teacher's Big Book of Graphic Organizers. San Fransisco: JosscyBass

Sharock, T., \& Martin, D. 2008. The Effect of Graphic Organizers on Students' Writing. Kennesaw State University.

Simarsih. 2013. TPS as an Effective Technique to Enhance the student's Achievement on Writing Descriptive Text. Malaysia : Universuty Utara Malaysia

Permendiknas No.41 Tahun 2007 tentang Standar Proses untuk Satuan Pendidikan Dasar dan Menengah

Purboningsih, D. (2015). Pengembangan Perangkat Pembelajaran dengan Pendekatan Guided Discovery pada Materi Barisan dan Deret untuk Siswa SMK Kelas X. Yogyakarta: Universitas Yogyakarta

When Chien, Chi. 2012. Use of Graphic Organizers in a Language Teacher's Professional Development. Taiwan : National Hsinchu University of Education 